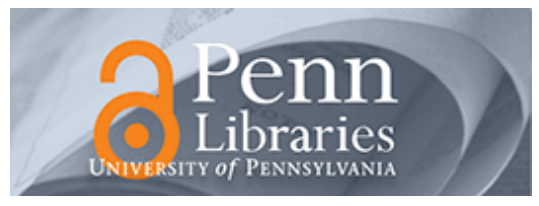

Studies in Visual Communication

Volume 9

Issue 3 Summer 1983

Article 3

1983

\title{
The Selling of the Empire: The Imperial Film Unit, 1926-1933
}

Paul Swann

\section{Recommended Citation}

Swann, P. (1983). The Selling of the Empire: The Imperial Film Unit, 1926-1933. 9 (3), 15-24. Retrieved from https://repository.upenn.edu/svc/vol9/iss3/3

This paper is posted at ScholarlyCommons. https://repository.upenn.edu/svc/vol9/iss3/3

For more information, please contact repository@pobox.upenn.edu. 
The Selling of the Empire: The Imperial Film Unit, 1926-1933

This contents is available in Studies in Visual Communication: https://repository.upenn.edu/svc/vol9/iss3/3 


\section{The Selling of the Empire:}

The Imperial Film Unit, 1926-1933

\section{Paul Swann}

The time has come when the British and the Dominion Governments should combine to produce a library of Imperial films to circulate round the Empire ... which would educate and stir the imagination and healthy patriotism of the coming generations. ${ }^{1}$

The massive economic recession which Great Britain experienced after the First World War transformed both film and the British Empire into subjects for public discussion. Industrial interests and the Conservative party tended to view the empire as a likely solution, if not the only one, to the decline of Britain's overseas markets and the malaise experienced by the staple industries. Stanley Baldwin spoke for most of his party when he declared in the midst of the 1924 General Election campaign that "the best hope for industrial revival (lay) in the development of the resources and trade of the British Empire" (Bigland 1926:14)

During the 1920s, there was a blurring of the distinctions between empire morale and empire trade. Both were felt to have been undermined by the American film industry, which made films promoting American mores and products that had flooded the international market in the wake of the First World War. As a consequence of the widespread awareness of the persuasive power of films, film publicity was regularly discussed at successive Imperial Conferences, ${ }^{2}$ and also within the ranks of the Conservative party. Significantly, the nontheatrical displays of propaganda films which the Conservatives employed from the mid-1920s often included films promoting the empire too (Hollins 1981:363). The comments of the 1926 Imperial Conference set the tone for the discussion of film publicity when it concluded that "it is of the greatest importance that a larger and increasing proportion of the films exhibited throughout the Empire should be of Empire production." 3

The 1926 Imperial Conference decided that each member must determine the legislative action it would adopt against the invasion of the American film. Apart from the high-sounding resolutions given out by this and later conferences, the only measures amounting to a common film policy for the empire were those taken by the Empire Marketing Board. The brief but eventful life of this offshoot of the Department of Overseas Trade has been examined in some detail previously (Lee 1972:49-57). In particular, its relation-

Paul Swann has a Ph.D. from the University of Leeds (England). He worked as a film researcher for the $B B C$ and is currently an Assistant Professor in the School of Communications and Theater, Temple University. Works in progress include an article on documentary film and the 1939 New York World's Fair. ship with the British documentary movement has received a considerable amount of attention, not least in the work of the documentarists themselves (The Arts Enquiry 1947; Rotha 1973; Watt 1974; Wright 1974). Typically, however, the movement is shown as developing directly in opposition to the intentions of its political masters. This ignores both the dramatic amount of interest in film publicity and the increasing sophistication of the discourse about film publicity on the part of many politicians and civil servants during the 1920s. It would be profitable to explore the early work of the documentary movement afresh in the light of this context.

\section{Empire Marketing Board}

The Empire Marketing Board was created as a consequence of Baldwin's ambivalent election victory in 1924. He did not believe that he received a mandate upon which the system of empire free trade, which he favored, could be based. Yet his policies committed him to aiding the development of imperial trade (Huxley 1970:125). The Empire Marketing Board came about as a compromise measure, intended to encourage trade without any assistance from tariff restrictions. The board's primary function was initially the promotion of scientific research and the development of a body of intelligence about markets within the empire. At the outset, publicity on behalf of empire products received only 15 percent of the board's budget, marketing 20 percent, and research 65 percent. The board's intended bias in favor of research was belied by the "conspicuous success" of its publicity efforts, especially in the area of posters, press advertisement, and film (Amery 1953:348)

From its birth in 1926 until 1930, the board publicized empire produce in Great Britain. From 1931, after the Imperial Economic Conference widened its brief, the board began publicizing British goods in the rest of the empire. This decision to expand the board's functions was almost simultaneous with action on the part of the Colonial and Dominions Secretary, J. H. Thomas, to bring about the abolition of the board. ${ }^{4}$ The entry of a government department into the field of commercial publicity on the scale envisaged by the Empire Marketing Board would have been quite impossible prior to the First World War. The war set a precedent for large-scale publicity within Britain, when many government departments found it necessary to communicate extensively with the general public. The war's disruption of the international economy also made this new venture in official commercial publicity necessary. Sir Stephen Tallents, secretary of the E.M.B. throughout its existence, was largely responsible for its creative approach to public ity and public relations. Under his guidance the board 
became an enthusiastic sponsor of all types of publicity, especially in the area of posters and films.

One of the board's first actions was to set up a film subcommittee. In the first instance, this committee was intended to oversee the production of a feature film to be made in association with Rudyard Kipling. It soon found itself discussing general film policy for the E.M.B. ${ }^{5}$ It was inevitable that the board would become involved in film publicity and attempt to exploit what was generally thought of as a most potent means of persuasion. Serious attention to films as publicity had been largely generated in Britain in the 1920 s by concern about the overwhelming predominance of the American film industry all over the world, but especially in Britain and the empire. In 1925, the year that at one time Britain did not have a single major feature film being made in its studios, ${ }^{6}$ the United States supplied over 90 percent of the films exhibited in Britain. By 1927, the United Kingdom had become "the largest American market in Europe and by far the largest revenue market in the world, outside of the United States "17 for the American film industry. The arrival of the sound film the same year, which seemed likely to affect the sale of American films in nonEnglish-speaking countries, threatened to make the British film market even more important for the Americans.

\section{Trade Follows the Film}

In the course of the heated discussions about protection for the film industry in the trade press and in the House of Commons, which resulted ultimately in the 1927 Cinematographic Films Act, the decline of Britain's economic status was attributed to the international success of the American feature film almost as a matter of course. Hollywood was acknowledged to have a profound effect upon consumer tastes and behavior wherever its films were exhibited. In the United States, publicists and the first generation of public relations experts were equally convinced of the value of film publicity. They believed, in the words of Edward L. Bernays (1928:156), that:

the American motion picture is the greatest unconscious carrier of propaganda in the world today. It is a great distributor for ideas and opinions.

British politicians and businessmen shared the views of Bernays, Lasswell, Lippmann, and the other American theorists. They provided many initiatives to challenge the supremacy of the American film and to build up British film production. In 1923, for example, a British Film League was established for the purpose of encouraging the production and distribution of British films. ${ }^{8}$ In 1924 there began the "gigantic pub- licity campaign," as L'Estrange Fawcett termed it, directed against the "American film invasion." He regarded this as little more than a "press stunt" which took the form of

newspaper leaders, special articles, and questions in Parliament; full-dress debates in both houses; visits to America and Germany to study conditions; attacks on the morals of foreign films, and efforts to prove that film was leading to an increase in juvenile crime. [Fawcett 1927:21]

One outcome of this considerable agitation was the creation of the Empire Film Institute, commissioned to promote the production of films within and about the empire. ${ }^{9}$

It soon became apparent in the lobbying that took place prior to the passing of the Cinematograph Films Act that British film producers and film renters did not have the same interests. Renters and exhibitors relied on American feature films for their profits. They maintained that their audiences wanted American films in preference to the British product. Politicians and film producers believed, however, that there was a real demand for British films by British audiences. In the absence of any real evidence about film audience preferences, opinion on this point remained strongly divided. The film industry found it impossible to develop a unified policy with regard to the regulation of American films in Britain until one was imposed on them by the government, and the different parts of the industry became the "bitterest enemies imaginable" (ibid.:14). The exhibitors were widely believed to be responsible for this schism, for, as Sir Oswald Stoll, producer and distributor commented:

Exhibitors apparently prefer to please themselves rather than to please the public, and they utterly disregard public sentiment. British exhibitors are obsessed by American pictures, but the general public are not ... the British people in ordinary circumstances are sufficiently catholic in taste to wish to see films of every nationality, but they never at any time have desired to see them instead of pictures of their own, wherein they can see British atmosphere and revel in the feeling that there is no place like home. $^{10}$

"Trade follows the film" became a widely heard slogan in the campaign against the American film invasion. It was coined by the editor of Kine Weekly in an article calling for increased production of films about Britain and the empire. He, like Stoll, believed that the cinema-going public in this country and in the rest of the empire wanted British films:

It is horrible to think that the British Empire is receiving its education from a place called Hollywood. The Dominions would rather have a picture with a wholesome, honest British background, something that gives British senti- 
ment, something that is honest to our traditions, than the abortions we get from Hollywood ... the American film is everywhere and is the best advertisement of American trade and commerce. ${ }^{11}$

In the United States, the leaders of the film industry were equally prompt in relating their feature film exports to the sale of American goods abroad. Joseph $P$. Kennedy, speaking to the students at the Graduate School of Business at Harvard in 1927, soon after he had taken over RKO Studios, maintained that "one of the most formidable trade obstacles" faced by foreign traders with the United States was that "American films were serving as silent salesmen for other products of American industry" (1927:6)

The E.M.B.'s first move against the publicity generated by American feature film predated any connection with John Grierson and the documentary movement. Rudyard Kipling expressed a desire to work with the board on the production of a film publicizing the empire. Kipling had recently begun to involve himself in a number of efforts to stir public interest in the empire in addition to his novels and poetry. In 1924, Kipling had played a major part in organizing a "Pageant of Empire" at the massive Empire Exhibition held at Wimbledon. Subsequently, he wrote a scenario for a film for the E.M.B. which strongly resembled the manner in which the pageant had been organized. Kipling's film treatment used a story about the gathering of the ingredients for the royal Christmas pudding as a vehicle for parading the diverse parts of the empire before the cinema audience. $^{12}$

The E.M.B. Film Committee believed that Kipling's name, since he was one of the major popular novelists of the day, was a "great commercial asset" for the film, so one of the conditions he stipulated for his cooperation was willingly accepted: that the board should employ Major Walter Creighton, with whom Kipling had worked organizing military tattoos at Aldershot, as the director for the proposed film. The committee, anxious to enlist Kipling's support, found itself being persuaded that Creighton was "particularly well qualified to assist the Board in the production of a suitable film, though he was admittedly unacquainted with film technique."13 The board soon had cause to regret the decision to employ Creighton. The production of his film, which was intended to be a major budget feature film capable of competing in the cinemas against American films, soon became a long and drawn-out affair. Virtually nothing was done in the first year Creighton worked at the board, during which he toured the empire looking for suitable locations and traveled to foreign film studios to learn film techniques. It soon became evident that this expensive production was not going to be the dynamic rebuttal to Hollywood that the board had intended to produce.

\section{John Grierson}

John Grierson arrived at the E.M.B. soon after Creighton's appointment in April 1927. He had just spent two years in the United States, where he had become thoroughly cognizant with modern publicity methods and had investigated the film industry. $\mathrm{He}$ had also been introduced to Russian film technique when he lived in New York, where he had helped to prepare the English subtitles for the American version of Eisenstein's Battleship Potemkin (Hardy 1979: $40-41) .{ }^{14}$ Grierson was drawn to the board, which appeared to be one of the few institutions in Britain interested in both public relations and films, with which he had been so concerned in the United States. Tallents commissioned him to produce a series of reports on the international film industry and the potential use of films for empire propaganda. These memoranda were strongly influenced by his visit to America and recent visits to France and Germany. He stated immediately that it would be quite impossible for either the British film industry or a government department to effectively challenge Hollywood on its own terms. He believed that Britain should establish a reputation in the field of the "authentic" film, exploiting the "visually dramatic material in which the Empire is so rich," and should not try to compete directly with the American feature film. He maintained:

while American producers cannot be expected to welcome English pictures which merely imitate in an inferior way the American model, there would be a great box office reception for English films which struck out on new lines and added to variety of production. ${ }^{15}$

Grierson proposed the production of a series of short actuality films based on "the ships, the docks, the factories, the furnaces, the streets, the canals, the plains, the caravans, the dams (and) the bridges" of the empire. This production program would be able to draw upon Britain's well-developed tradition in the actuality film. ${ }^{16}$ The necessity of heavy investment in feature films made it very difficult to rehabilitate that side of the industry, so as an alternative he advocated the creation of a central government film production unit. He praised the efforts of the official filmmakers working in Soviet Russia and cited them as the model for filmmaking at the E.M.B. ${ }^{17}$

Grierson was indebted to the Russians for his ideas for film subjects and treatments. He had been converted to their ideas about the use of montage, and he now argued that the real world could be energized and transformed through film editing, which could dramatize even the most mundane material. He believed that "even where there is no story, the visual aspects of a seemingly prosaic subject can be orchestrated into a cinematic sequence of enormous vitality" (see Figures 1 and 2). ${ }^{18}$ 
Grierson commented that there were few films upon which the E.M.B. could rely for its publicity efforts. He believed that the board would have to produce this series of carefully edited actuality films itself. The greater part of the board's film budget was devoted to the production of Creighton's film. Grierson therefore employed a stratagem to win financial backing for a further film which was later recounted by Tallents. Arthur Samuel, Financial Secretary to the Treasury, was also the country's leading authority on the home herring industry. Consequently, as Tallents later put it:

We baited our hook with the project of a film to illustrate the North Sea herring fisheries. The Treasury swallowed it, and Grierson set out to make his first film. ${ }^{19}$

The critical and financial success of Grierson's film, Drifters (1929), greatly assisted his reputation. He became known to both the film society circuit and to politicians. He was even introduced to the Cabinet, for whom he arranged a special screening of a group of relevant films (Hardy 1979:48).

By 1930, Grierson's comments were reaching a number of influential politicians and civil servants. He had begun to popularize the statements of Will Hays, president of the Motion Pictures Producers and Distributors of America (the Hays Office), on the value of films as "incidental publicity" for industry and commerce. Hays, a former Cabinet member and a leading spokesman for the American film industry, was very aware of the way in which films advertised his country's "clothes, office equipment, machinery, automobiles, furniture (and) architecture to all parts of the world" (Hays 1929:27). Taking for his title a statement by Hays that "one foot of film equals one dollar of trade," Grierson (1931) argued that:

the relationship of film values to trade returns is possibly better understood in the States than it is here. The film business has not yet taken itself seriously enough as a national asset.

His authoritative statements on the importance of films as trade propaganda in the trade press and in his official reports led to Grierson's appointment as film adviser to a special Inter-Departmental Committee on Trade Advertisement and Propaganda set up under the auspices of the Department of Overseas Trade in February 1930.20

Grierson produced a special report on the use of films for empire trade propaganda and film publicity in general, which led to the creation of a separate Films Sub-Committee. In his report, Grierson criticized the idea of using "incidental publicity" in feature films to promote British and empire products. The principal objections he raised were the very limited distribution of British feature films and their traditionally "shabby"

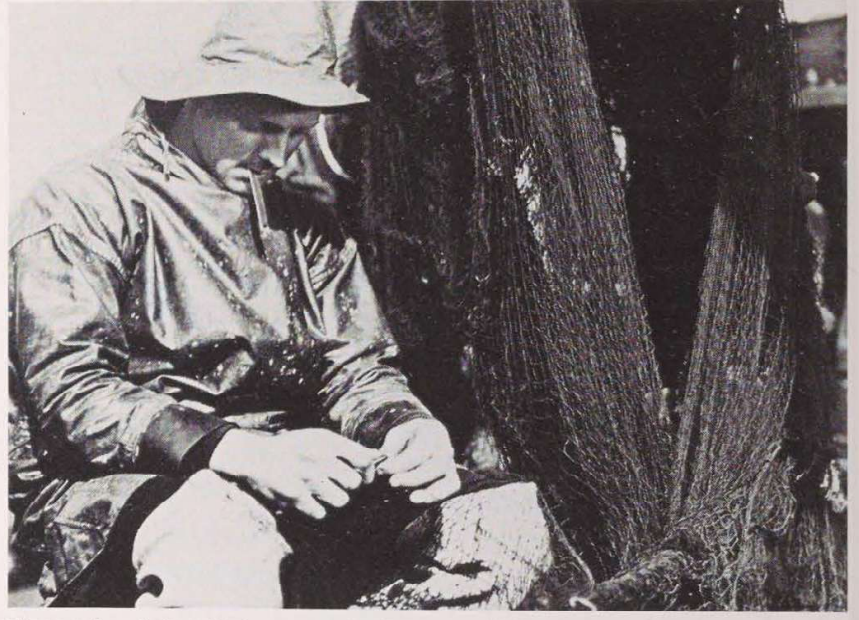

Figure 1 John Grierson, Drifters, 1929. Photo courtesy of National Film Archive, London.

Figure 2 John Grierson, Drifters, 1929. Photo courtesy of National Film Archive, London.

production values, which severely limited the extent to which British commodities could be shown in a good light to cinema audiences. ${ }^{21}$ As an alternative, he again called for the production of more films like his own Drifters, aimed at the second-feature market. He also maintained that the government ought to persuade the newsreel companies to include more material on the empire in their films, something which the Joint Films Committee of the British Council and the Travel Association attempted to do with considerable success later in the decade. ${ }^{22}$ Finally, Grierson called for the production of a great number of simple "poster" films directly advertising products on the lines of those being produced by the young men and women he had begun to recruit at the E.M.B

After his comments about the directions in which official film production should go, Grierson also anticipated the manner in which documentary films would be exhibited in later years. He maintained in his report for the Inter-Departmental Committee that publicity films of the type he advocated should be directed at the nontheatrical audiences outside the commercial cinema. His belief that there were large nontheatrical audiences of this type had been largely inspired by the success of the Canadian Government Motion Picture Bureau. Since its inception, this organization had been run by Frank Badgeley, who had built up its 


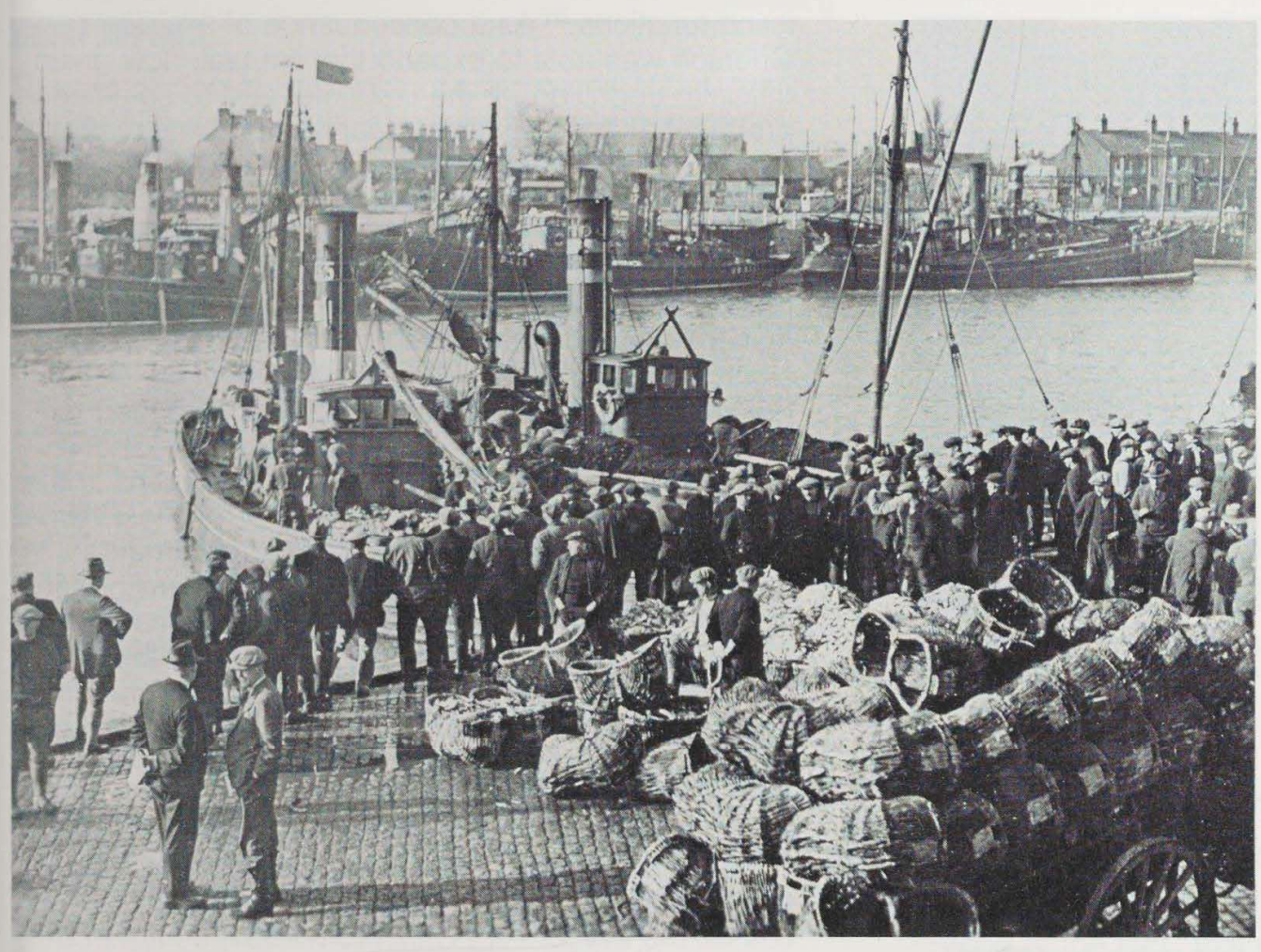

activities in the production and distribution of nontheatrical films publicizing Canada, particularly in the United States. The Canadian example was very exciting for Grierson. No country was more vulnerable to the intrusion of American films and their inherent propaganda than Canada, yet the bureau appeared to be meeting this challenge with the distribution of its films on a nontheatrical basis in the United States. In 1928, Badgeley claimed his organization was reaching 20 million Americans each year with the 3,000 short films it had being distributed nontheatrically in the United States. ${ }^{23}$

In his reports for both the E.M.B. and the Inter-Departmental Committee, Grierson called for the production of a series of quality short documentary films. Initially, by way of beginning production, he suggested that six films dealing with empire publicity should be made each year. ${ }^{24} \mathrm{He}$ believed that the empire offered a plethora of film material just as stirring as the American West or Russia's steppes. He waxed lyrical about the films that could be made about "the arrival of a ship from the East in the Port of London in the evening (with Lascars chanting) or the squabble of the lamb sales at Lanark." 25 Grierson believed not only that documentary films could publicize the empire, but also that the empire deserved to be publicized. The empire was potentially an agent for social and political change on a massive scale. The Knoxist notion of "stewardship" and its application to the rise of modern communications was a central part of Grierson's philosophy throughout his life. In the 1920s, this was manifested in the image of an efficient and benevolent British Empire.

\section{The E.M.B. Films}

"Selling the Empire" was for Grierson an application of the publicity and public relations devices he had seen employed by big business in the United States for a much more important and worthwhile cause. On a practical level, the E.M.B.'s film publicity initially had to take the form of advertising specific commodities. However, the overall end in view was the promotion of the empire as a whole. The majority of the films made by the group of young filmmakers Grierson gathered together at the E.M.B. comprised the simple "poster" films which he had advocated in reports for the board and the Inter-Departmental Committee. ${ }^{26}$ Generally these films were created out of found film footage, usually garnered from Canada and the other Dominions. The films were silent and derived their ef- 


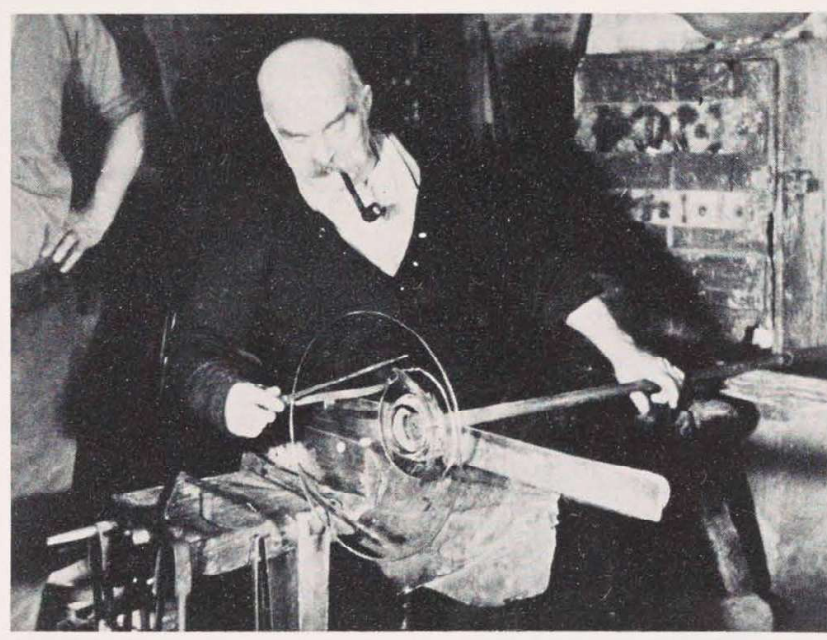

Figure 3 Robert Flaherty, Industrial Britain, 1932. Photo courtesy of National Film Archive, London.

fect from editing. Poster films advertising Australian white wine and New Zealand lamb, for example, were displayed in public locations on daylight projectors. These films were generally thought to be very effective, and on one occasion, Grierson was pleased to report the news that he had been asked to remove a projector which had been running in Victoria Station. The projector, perhaps more than the film it had been showing, had aroused so much attention that it had stopped pedestrian traffic in the station (Hardy 1979:48).

The poster films were a good training ground for Basil Wright and the other early recruits to the E.M.B. Film Unit, which Grierson began to establish after the success of his own first film. They were especially useful for the development of editing skills and led to a strong emphasis on montage effects in the early work of the documentary movement. Obviously, these films were severely limited in scope and potential impact, although it is interesting to remember that many of the Russian filmmakers of the 1920s, including Eisenstein, had also made their first films out of existing footage after supplies of new film stock had been disrupted during the war (Leyda 1964:23-27). ${ }^{27}$ Grierson was anxious for his unit to make the same transition, from using existing film footage to making films out of wholly new material, that the Russians had already accomplished with such spectacular success.

The 1930 Imperial Conference, which, like its predecessor, acknowledged the value of film "for propaganda purposes, whether direct or indirect, in connection with inter-Imperial trade," widened the brief of the E.M.B. to include the promotion of British products in the rest of the empire in addition to its ex- isting functions. ${ }^{28}$ As a consequence of this decision, Grierson was able to expand the film unit, now given official recognition for the first time, and to commence production of the series of quality short films made out of freshly shot material, which he had been demanding for the previous three years. In 1931, the members of the unit began work on six films including one major production, Industrial Britain, which was made with the assistance of the great American filmmaker Robert Flaherty (see Figure 3). All six films, significantly, dealt with various aspects of life in Britain. They were made as silent films, intended for commercial distribution. Grierson discovered that it was impossible to get distribution of silent films in the movie houses, which by 1932 had been almost completely converted to sound. This disappointment came at exactly the same time that the board began to curtail its publicity work, as a consequence of which there was no money to add sound to the films to make them more attractive to the distributors. The films, packaged together as the "Imperial Six," were later sold outright to Gaumont British, which added its own sound track to the films. ${ }^{29}$

It is ironic that interest in commercial publicity for the empire began to wane at precisely the moment that Grierson won access to major production facilities for the E.M.B. Film Unit. From 1931, as the economic depression continued unabated and the activities of the board seemed to be ineffectual, it began to lose the esteem of both politicians and the public - so much so, that when the abolition of the board was finally announced, it was widely acclaimed as a "piece of national economy long overdue." 30 Tallents was largely responsible for sustaining the board for two more years in the face of mounting opposition (Lee 1972). He believed that the publicity work of the board, especially its efforts in film, were too important to be allowed to slip away. The remaining life-span of the E.M.B. Film Unit was too brief for it to produce any major productions about the empire after the Imperial Six. The definitive statement about the British Empire from the early documentary movement was therefore made after the demise of the unit, when Tallents and Grierson had transferred their activities to the Post Office. This was Basil Wright's Song of Ceylon (1935), made for the Ceylon Tea Propaganda Board. 


\section{Basil Wright}

The production of Basil Wright's film came about after Gervas Huxley, Tallents' chief assistant on publicity matters at the E.M.B., was appointed head of the Ceylon Tea Propaganda Board. Huxley arranged for the sponsorship of a major film production along the lines of those recently made by the board. ${ }^{31}$ This brilliant and still charming film can be seen as an exposition of the views of the young documentary movement on the British Empire. It was one of the first sound films in which a member of the movement exercised complete control over sound and images. Typically, Wright took the opportunity to experiment with the use of sound, and images and sound track were neatly counterpointed. Perhaps the clearest instance of this is the contrast between the European voices which dominate the sound track, although not in the form of a conventional voice-over narration, and the Asiatic images - the dancers, the plantation workers, the scenery, and of course, the Buddha-which cover the screen. The Buddha becomes a metaphor for the whole of Ceylon. When there is an Asiatic presence on the sound track, it usually takes the form of music or sound effects.

The film carried all the implications of the sponsorship system which supported the British documentary film. It is in no sense an indictment of British colonial rule. The production and transportation of tea, the quintessential British drink, made possible by a complex mixture of commerce and colonial rule, could have been the occasion for a critique of the empire. This was not Wright's intention, since neither he nor his colleagues felt at this point that the empire should be criticized while they were making films promoting its products. The empire and colonial rule in general did not have the negative connotations they came to have in later years. Only the Left, which had only a peripheral involvement with the documentary movement, was committed to a wholesale condemnation of the British Empire.

In later years, the documentarists maintained that their relationship with the E.M.B. had been a necessary evil. They had been forced into a compromise in order to develop a national school of purposive filmmaking, which subsequently proved very valuable. They emphasized those of their films that publicized social issues, such as unemployment, health, and housing, and their role as propagandists during the war, downplaying their early involvement with empire publicity. In effect, they claimed that the most important aspect of their work at the E.M.B. was that it was a beginning. For example, Paul Rotha, who worked for Grierson very briefly at the board, maintained that the early interests of the documentary movement during the life of the E.M.B. had been purely aesthetic. As he said recently, "we couldn't care less about

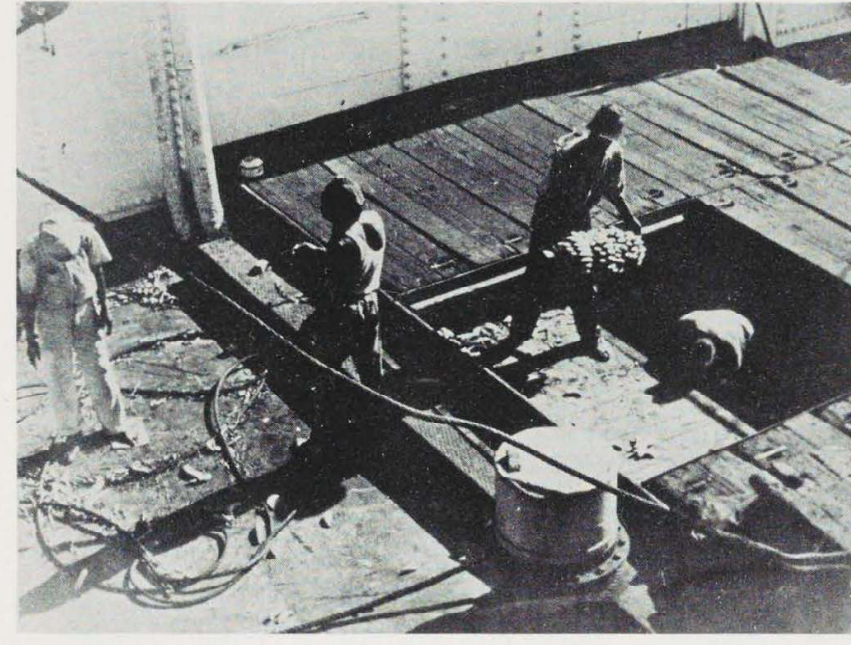

Figure 4 Basil Wright, Cargo from Jamaica, 1933. Photo courtesy of National Film Archive, London.

Empire butter or Empire timber or whatever it was" (quoted in Sussex 1975:15). In this view of events, politicians and civil servants are characterized as "proud of the fact" that they knew nothing about films and their utility as a means of information (Watt 1974). Grierson is credited with having "sold" the idea of the documentary film to a group of unreceptive officials. Such a view does not take into account the high level of interest in using film publicity, especially in connection with the empire and its products, which had been evidenced long before the creation of the Empire Marketing Board.

There were very occasional instances when filmmakers included a criticism of some aspect of the empire in their films. Basil Wright, for example, took the opportunity in Cargo from Jamaica (1932; see Figure 4) to implicitly comment upon the laborious, back-breaking methods used to loads goods in Kingston (Wildenhahn 1977:21). The film is the rare exception which proves the rule, and it seems on the whole that the documentary group were comfortable promoting the image and commodities of the British Empire. In the late twenties, it was still very possible to be idealistic about the empire. It could be understood as a challenging and worthwhile cause, deserving the best efforts of the documentarists. This was in stark contrast to the documentarists' views about Hollywood and the American feature film, and, implicitly, the British feature film industry.

Grierson and his followers believed that American feature films were comprised of great skill and a great deal of money, wedded to shoddy and superficial intentions. As far as Paul Rotha (1931:52) was con- 
cerned, "Many films from Hollywood are staged with the chaotic sentiments which characterise that amazing city which possesses no ideology." Grierson believed that the feature film industry did not act responsibly. He felt it ought to be doing much more than selling escapism:

In an age when the faiths, the loyalties and the purposes have been more than usually undermined, mental fatigue represents a large factor in everyday experience. Our cinema magnate does no more than exploit the occasion He also, more or less frankly, is a dope peddler. [cited in Hardy 1966:171]

The techniques and style of the feature film industry were largely rejected by the documentary group, and Russia's "purposive" school of filmmakers became the model for their work, not Hollywood. One consequence of this use of the Russian example was that British documentary films were usually characterized by a strong didactic element. These filmmakers be lieved that the nontheatrical documentary film was destined to be an important tool for international education. Paul Rotha (1931:42) wrote:

It is probable that within ten years time the cinema will be the principal means of education for both adults and children, and that the comprehensive ideas which the Soviets have already put in hand for cinematic teaching will have spread to every country.

\section{Distribution and Impact of the E.M.B. Films}

The reception which the documentarists' films received did not correspond to the enthusiasm with which they were made and publicized. The technical difficulties surrounding the distribution of their silent films has already been noted. Much more insurmountable a problem was the attitude of the film distributors and exhibitors, who, except for their initially warm reaction to Drifters, were almost invariably hostile toward the work of Grierson's followers. Exhibitors were certain, in the words of their association's president, Theo Fligelstone, that "the public will not be educated. "32 They believed there was no place for the documentary film, whether it promoted the products of the empire or the gas industry, in their theaters. The tendency to drive documentaries out of the motion picture theater was reinforced by the growth of the double-feature program, which, as Grierson noted, left no room for his films. ${ }^{33}$ The difficulties encountered in obtaining rentals for their films encouraged the documentarists to look to the nontheatrical film markets for their major outlet. It was perhaps here, rather than in the few films which received some distribution in the theaters, or the poster films the unit made, that the documentarists made real progress in selling the empire to people in Britain and abroad.

The Imperial Institute, which was originally the only screening facility for the E.M.B.'s films on a nontheatrical basis grew into a large-scale distributor for documentary films. In October 1931, the E.M.B. Film Library was formally brought into existence. Its films were seen mainly by schoolchildren watching $16-\mathrm{mm}$ prints. In its first year, 517,000 people saw the library's films, three-quarters of them children. By 1936, operated in conjunction with the Post Office Film Library, the Empire Film Library, as the board's collection was now called, was estimated to be reaching five million people each year. ${ }^{35}$ Again, the greater part of these nontheatrical audiences were schoolchildren. Grierson remained constantly optimistic about the prospects for this type of film distribution, although he tended to play down the youthful audiences that his films were reaching

Many children must have received their first glimpses of the British Empire in the E.M.B. films borrowed by their teachers. In the early thirties the empire did not figure prominently in films made in either Britain or the United States. In effect, the documentarists' films took up the theme of the British Empire before it was taken up in many films made by the industry after the middle of the decade. Young film audiences may have been impressed by those parts of the empire they saw in F.M.B. films and been pre pared by them for those fiction films made by the industry which used the empire as a backdrop a few years later. Films distributed in this manner, however, could have had little effect upon the sale of empire products in Britain, which had been the original end in view.

It is very difficult to define the impact of the rest of the E.M.B.'s film publicity. One reason for this is that Grierson usually supplied the figures for attendance at performances, numbers of films booked, numbers of films screened, and so on, and he was invariably generous and optimistic in his interpretation of these figures. Grierson's own Drifters and Wright's Song of Ceylon were virtually the only major documentary films made during this period that were given substantial commercial bookings. Generally, Grierson's films were unable to break into large-scale distribution. This was a very disappointing failure for Grierson's political masters. They had already witnessed the dismal performance of their attempted production of a major feature film. The film made for the board by Walter Creighton was eventually released as One Family (1930). After eating up the greater part of the board's film budget each year, the film had gone on to become a complete disaster at the box office ${ }^{36}$ Grierson's rhetoric about the use of a totally different type of film, the inexpensive short actuality film, intended to publicize the empire through 
the second-feature market, had therefore reached a very receptive audience. Grierson was unable to deliver empire publicity through the movie houses, and the development of the nontheatrical audiences must have taken much longer than he had expected.

\section{The Decline of the E.M.B.}

The notion of exploiting the empire connections for the sake of industrial revival in Britain was falling from favor at the same time that Grierson and his followers began to look for a source of inspiration for their work other than the empire. In the late 1920s, the whole question of Britain, the empire, and the cultural domination of American films had been a major public debate. For somebody returning to England after becoming familiar with American publicity techniques, as Grierson was, it was a natural field for making a reputation. Gradually, however, the domestic industry was able to take up the challenge of the American film industry. This was a consequence of the quotas established by the Cinematograph Films Act and the return of British investment capital to underwrite the film industry. ${ }^{37}$ The recovery of the British industry, especially when guided by patriots like Alexander Korda and Michael Balcon, offered the prospect of forcing the American feature film out of British and Empire theaters without heavy official involvement. This eroded the amount of official support upon which Grierson could expect to draw. In addition, as the international economic depression continued, the empire ceased to be viewed as the panacea for Britain's ills which it had once been. As the last years in the life of the E.M.B. passed, Grierson perceived that there was only a limited amount of prestige to be gained from making films promoting the empire. By September 1933, as Tallents and Grierson moved over to the Post Office, the latter had already begun to look to industry and to social issues, rather than government departments and the empire, for the future funding and themes for the school of filmmaking he had created.

In 1926, the year the E.M.B. was established, the discussion about Britain, the empire, and films had been at its most intense. The editor of The Times complained:

It is probable that more has been said and written during the last year about the connection between British films and the British Empire than ever before. It is certain that less has been done. Everybody realises what wonderful propaganda the film may provide. Countless people write and talk about it, but no one does anything. ${ }^{38}$
Grierson had been very fortunate to return to Britain at this key moment; it gave his pronouncements much more weight than they would otherwise have had. This is not to imply that Grierson's involvement with empire publicity was purely opportunistic. He was genuinely committed to his work at the board, and he found inspiration in the far reaches of the empire; he thought its defense against the incursion of the American feature film well worthwhile. Only a short while after Grierson's group had begun to congregate at the E.M.B., he decided that domestic social issues were more pressing than empire publicity.

Grierson's real ambition was to create a national school of filmmaking, and, writing a defense of his prodigy in 1932, he maintained it was

the only hopeful possibility of which we are presently aware of freeing British films from slavish competition with American methods and of establishing for them a character of their own. ${ }^{39}$

He thought that, once established, such a school could serve a multiplicity of functions, working for all branches of the government. This vision of an omnicompetent and impartial group of information experts mediating between the public and government came directly from Walter Lippmann's Public Opinion (Lippmann 1922). The documentary movement grew in the wake of widespread concern about the empire and a widespread awareness of the efficacy of film publicity. When this source of patronage dried up, Grierson looked elsewhere for support. In the interim, in the small number of documentary films that won theatrical distribution, in the poster films which dotted railway stations and exhibitions up and down the country, and in the potentially important system of nontheatrical distribution, the documentary movement did what it could to provide the British public with film images of the empire and its products.

\section{Notes}

1 Sir James Marchant, quoting a speech by the Prince of Wales, The Times, June 11, 1924, p. 8.

21926 Imperial Conference, CMD 2768, p. 53; 1930 Imperial Conference, CMD 3718, pp. 238-240; 1932 Imperial Economic Conference, CMD 4175; pp. 50-53.

3 Appendices to the Summary of the Proceedings of the 1926 Imperial Conference, CMD 2769, p. 406.

4 Report of the Committee on National Expenditure, July 1931, CMD 3920, pp. 131-132.

5 S. Tallents, "Proposal for the Preparation of a Film under the Auspices of the E.M.B.," January 27, 1927, P.R.O. C.O. 760/37, $\mathrm{EMB} / \mathrm{C} / 1$

6 Memorandum presented to the Moyne Committee by the Association of Cinematograph Technicians, May 13, 1936, P.R.O. B.T. 55/3, CCF 1. George Pearson had taken Satan's Sister (1926) to the West Indies for location work.

71928 Film Daily Yearbook (New York, 1928), p. 1006. 
8 The Times, January 2, 1924, p. 18

g Sir Alfred Mond proposed a toast to "Films and Empire" at the inaugural dinner of the British Empire Film Institute, April 22, 1926.

10 The Times, January 2, 1924, p. 18

11 Kine Weekly, June 12, 1930, p. 3.

12 Tallents, op.cit

13 E.M.B. Film Committee Minutes, February 1, 1927, P.R.O. C.O $760 / 37$

14 Grierson assisted in preparing the subtitles for Potemkin; he did not reedit it for its American premiere, as is often suggested.

15 John Grierson, "Notes for English Producers," April 29, 1927 P.R.O. C.O. $760 / 37 \mathrm{EMB} / \mathrm{C} / 2$

16 Percy Smith was making the World Before Your Eyes series for Charles Urban before the First World War. Using time lapse and micro-photography, he introduced many cinema audiences to the secrets of nature, as his next series was called. In addition, Harry Bruce Woolfe and Andrew Buchanan both produced many actuality films after the war.

17 Grierson, "Further Notes on Cinema Production," July 28, 1927 P.R.O. C.O. $760 / 37 \mathrm{EMB} / \mathrm{C} / 2$

18 Grierson, note 15 , op cit.

19 S. Tallents, cited in F. Hardy (1966:17)

20 Inter-Departmental Committee on Trade Advertisement and Propaganda Minutes, P.R.O. B.T. 61/40/1 E 12251

21 Grierson, "Film Propaganda," July 1930, P.R.O. B.T. 61/40/1 E 12251 B Paper No. 14

22 The Joint Films Committee decided that "the judicious exploitation of the newsreel ... . is far more convincing than any fabricated propaganda product." Joint Film Committee Minutes, November 1938, P.R.O. B.W./2/214 GB/30/1

231928 Film Daily Yearbook, p. 927.

24 Grierson, note 21, op. cit

25 Grierson, note 21 , op. cit

26 Paul Rotha believes the poster films were the forerunners of mod ern television commercials, without "luscious high budgets and expensive technical devices" (1973:49)

27 Dziga Vertov's History of the Civil War (1922) and the series of films Esther Schub made about Tsarist Russia, beginning with Fall of the Romanov Dynasty (1927) pioneered the revolutionary use of "recycled" film in Soviet Russia.

28 Proceedings of the 1930 Imperial Conference, November 1930 CMD 3717 , p. 52

29 O'er Hill and Dale, Upstream, Shadow On The Mountain, Country Comes To Town, King Log and Industrial Britain (all 1931-1932). were sold for 2,000 pounds in cash, plus a third of receipts over 8,000 pounds. The nontheatrical rights on the films reverted to the E.M.B. after 12 months. S. Tallents, "Note on Formal Agreement between the E.M.B. and Ideal Films Ltd." "January 25, 1933, P.R.O. C. $0.760 / 37 \mathrm{EMB} / \mathrm{C} / 83$

30 Sir Edward Parry, The Times, September 1, 1933, p. 12

31 G. Huxley, "Tea On The Films," The Times, July 14, 1933, p. 15

32 Moyne Committee Minutes, May 26, 1936, P.R.O. B.T. 55/4 CCF 2

33 Robinson to Tallents, reporting on a conversation with Grierson, November 27, 1935, P.R.O. T. 160/742 F 13860/03/3

34 "Report on non-theatrical distribution of E.M.B. films," October 1932, P.R.O. C.O. $760 / 37$ EMB/C/81.

35 Lindsay to the Secretary, the Board of Trade, March 31, 1937 P.R.O. T. $161 / 844$ S 41901.

36 One Family cost 15,740 pounds; its total rentals amounted to 334 pounds, which did not cover the cost of the brass band attending its premiere. E.M.B. Progress Report, September 18, 1930, P.R.O C. $0.760 / 37 \mathrm{EMB} / \mathrm{C} / 49$.

37 Cf. Legg and Klingender (1937), a pioneering study of the finances of the British film industry.

38 The Times, May 24, 1926, p. 14.

39 Grierson, "Films of Substance," The Times, April 2, 1932, p. 8

\section{References}

- Amery, L. S

1953 My Political Life. Vol. II. London: Hutchinson.

- The Arts Enquiry

1947 The Factual Film. London: Oxford University Press

- Bernays, E. L.

1928 Propaganda. New York: H. Liveright.

- Bigland, A.

1926 The British Empire. London: C. Palmer

- Fawcett, L

1927 Films, Facts and Forecasts. London: G. Bles.

- Grierson, J.

1931 One Foot of Film Equals One Dollar of Trade. Kine Weekly (January 8)

- Hardy, F

1979 John Grierson. London: Faber \& Faber.

- ed.

1966 Grierson on Documentary. London: Faber \& Faber.

- Hays, W. H.

1929 See and Hear. New York: Motion Picture Producers and Distributors of America.

- Hollins, T. J

1981 The Conservative Party and Film Propaganda between the Wars. English Historical Review (April):36

- Huxley, G.

1970 Both Hands. London: Chatto \& Windus.

- Kennedy, J.P., ed

1927 The Story of the Films. Chicago and New York: A. W. Shaw.

- Lee, J. M.

1972 The Dissolution of the E.M.B., 1933; Reflections on a Diary. Journal of Imperial and Commonwealth History 1.

- Legg, S., and F. D. Klingender

1937 Money Behind the Screen. London: Lawrence and Wishart.

- Leyda, J.

1964 Films Beget Films. New York: Hill \& Wang

- Lippmann, Walter

1922 Public Opinion. London: Harcourt Brace.

- Rotha, Paul

1931 Celluloid: The Film Today. London: Longmans, Green and Co

1973 Documentary Diary. London: Secker \& Warburg.

- Sussex E

1975 The Rise and Fall of British Documentary. Berkeley, Cal.: University of California Press.

- Watt, $\mathrm{H}$.

1974 Don't Look at the Camera. London: Elek.

- Wildenhahn, K

1977 Approaches to the Legend. In Journey to a Legend and

- Wright, B

1974 The Long View. London: Secker \& Warburg 